\title{
Chronique dite de Jean de Venette, édition, traduction et présentation de Colette Beaune
}

\section{G. Matteo Roccati}

\section{Q OpenEdition}

1 Journals

\section{Édition électronique}

URL : http://journals.openedition.org/studifrancesi/2073

DOI : 10.4000/studifrancesi.2073

ISSN : 2421-5856

Éditeur

Rosenberg \& Sellier

\section{Édition imprimée}

Date de publication : 1 avril 2014

Pagination : 120

ISSN : 0039-2944

\section{Référence électronique}

G. Matteo Roccati, «Chronique dite de Jean de Venette, édition, traduction et présentation de Colette Beaune », Studi Francesi [En ligne], 172 (LVIII | I) | 2014, mis en ligne le 01 avril 2014, consulté le 18 septembre 2020. URL : http://journals.openedition.org/studifrancesi/2073 ; DOI : https://doi.org/ 10.4000/studifrancesi.2073

Ce document a été généré automatiquement le 18 septembre 2020.

\section{(c)}

Studi Francesi è distribuita con Licenza Creative Commons Attribuzione - Non commerciale - Non opere derivate 4.0 Internazionale. 


\title{
Chronique dite de Jean de Venette, édition, traduction et présentation de Colette Beaune
}

\author{
G. Matteo Roccati
}

\section{RÉFÉRENCE}

Chronique dite de Jean de Venette, édition, traduction et présentation de Colette BEAUNE, Paris, Librairie Générale Française, 2011 («Le livre de poche, Lettres gothiques», 31547), pp. 502.

1 L'introduction présente de manière vivante la chronique et son auteur (il ne s'agit pas du prieur Jean de Venette, mais sans doute d'un carme de son entourage), son approche comme historien, et son point de vue (attentif aux humbles, très critique parfois envers les nobles), qui est celui des ordres mendiants, sa conception du temps. L'indication des étapes essentielles de la tradition manuscrite et la liste des éditions suivent, ainsi que celle des chroniques et autres sources parallèles, enfin la bibliographie et une chronologie. Le texte latin (édité d'après le ms. Arundel 28) est imprimé avec la traduction française en regard et suivi des variantes et des notes, puis de plusieurs annexes (monnaies, poids et mesures, cartes, tables généalogiques). L'index des personnes et des lieux complète le volume. 